\title{
Excitation of the Double Chamber Right Ventricle: Electrophysiologic and Anatomic Correlation
}

\author{
CRAIG J. BYRUM, MD \\ MACDONALD DICK II, MD \\ DOUGLAS M. BEHRENDT, MD \\ PAUL HEES \\ AMNON ROSENTHAL, MD, FACC
}

Ann Arbor, Michigan
From the Sections of Pediatric Cardiology And Thoracic Surgery, C. S. Mott Children's Hospital, and the Departments of Pediatrics and Surgery, University of Michigan Medical Center, Ann Arbor, Michigan. Manuscript received June 30, 1981, revised manuscript received October 26, 1981, accepted October 29, 1981.

Address for reprints: Macdonald Dick II, MD F1115, Section of Pediatric Cardiology, C. S. Mott Children's Hospital, University of Michigan, 1405 East Ann Street, Ann Arbor, Michigan 48109.
To examine the excitation of the double chamber right ventricle and the possibility that it results from a displaced, hypertrophied moderator band, seven patients with double chamber right ventricle were studied. All seven had pre- and postoperative electrocardiograms. Intraoperative right ventricular epicardial maps were obtained in three; right ventricular endocardial activation maps performed at postoperative catheterization were obtained in four. In the three patients studied at operation the breakthrough point of right ventricular epicardial activation was demonstrated in a normal inferior location well below the obstructing muscle band. Two patients with right bundle branch block after operation and two others with only right ventricular conduction delay on postoperative electrocardiogram demonstrated high normal right ventricular time with prolongation of activation in the right ventricular outflow or inflow region, or both, suggesting only peripheral injury. These data suggest that activation of the double chamber right ventricle is similar to that of the normal heart. In addition, the observed normal activation sequence militates against the hypothesis that the moderator band is the obstructing bundle.

In the normal and abnormal heart the moderator band conveys the terminal portion of the right bundle branch of the specialized atrioventricular $(\mathrm{A}-\mathrm{V})$ conduction tissue to the anterolateral papillary muscle and the right ventricular free wall epicardium. ${ }^{1-3}$ The sequence of right ventricular excitation resulting from these morphologic features has been determined. ${ }^{4,5}$ However, although the clinical, hemodynamic, angiographic and pathologic features of double chamber right ventricle have been well described, ${ }^{6-13}$ no data exist on the pattern of right ventricular activation in this anomaly. These data are of special significance in view of the hypothesis that the obstruction within the double chamber right ventricle arises from superior displacement of the moderator band. ${ }^{10,14}$ Although this hypothesis would be perhaps best examined by histologic technique, useful information regarding anatomy can often be derived from examination of excitation sequences. ${ }^{15-17}$ Therefore, to examine both the right ventricular excitation sequence and its possible relation to the hypothesis concerning the anatomy of double chamber right ventricle, we studied seven patients with this anomaly using electrocardiographic and electrophysiologic techniques.

\section{Methods}

Study patients: Seven patients with double chamber right ventricle underwent cardiac catheterization. The patients ranged in age from 4 to 20 years. Before operation, right and left heart catheterization was performed in four, and right heart catheterization alone in three. Each patient had a right ventricular peak systolic intracavitary gradient ranging from 37 to $74 \mathrm{~mm} \mathrm{Hg}$; the angiographic criteria for double chamber right ventricle were fulfilled in each patient. ${ }^{12}$ Three patients demonstrated a low type and four patients a high type of double chamber right ventricle. All patients had a ventricular septal defect but none had clinical cyanosis.

Postoperative catheterization studies: All patients underwent resection of the obstructing muscle bundle through a ventriculotomy with closure of the 
ventricular septal defect. In four patients (Cases 3 to 6) postoperative catheterization demonstrated a residual peak systolic intracavitary gradients of 1 to $20 \mathrm{~mm} \mathrm{Hg}$. One of these patients (Case 6) with a high type of double chamber right ventricle also had severe fibromuscular subaortic stenosis (peak systolic ejection gradient $75 \mathrm{~mm} \mathrm{Hg}$ ) requiring subsequent operation. Postoperative hemodynamic study has not been performed in the other four patients; however, intraoperative pressure measurements at closure of the ventricular septal defect in three showed a reduction in right ventricular inflow pressure to 15 percent (Patient 1), 50 percent (Patient 2) and 18 percent (Patient 7) of the preoperative value. Additional supportive evidence of adequate relief of observation in these three patients is the reduction of grade $5 / 6$ murmurs in each patient to a grade $1-2 / 6$ murmur in Cases 1 and 2 and no murmur in Case 7. Patient 3 had complex anatomy with double outlet right ventricle as well as double chamber right ventricle and had a poor result with a significant residual ventricular septal defect.

Electrophysiologic studies: Pre- and postoperative standard 12 lead electrocardiograms were obtained in the seven patients. All mapping and catheter studies were performed during normal sinus rhythm. Three patients (Cases 1 to 3) underwent right ventricular epicardial surface mapping in the operating room just before surgical division of the obstructive muscle band. The epicardial electrograms recorded at operation were obtained from 18 to 22 sites on the right ventricular anterior free wall. Recordings were also made directly from the obstructing muscle bundle in Patients 2 and 3 but not in Patient 1. After operation, right ventricular endocardial activation times were determined at postoperative catheterization in four patients (Cases 3 to 6). 'The endocardial recording sites confirmed by fluoroscopy were the right ventricular apex, right ventricular outflow and right ventricular inflow regions.

Activation times were measured from the earliest onset of the QRS complex observed in three simultaneous reference surface electrocardiograms (usually leads I, II and III) to the first fast activation deflection to cross the isoelectric line of the respective bipolar electrogram. ${ }^{18,19} \mathrm{~A}$ mean value for endocardial activation times as well as for His bundle intervals was computed from analysis of three to five consecutive beats. The endocardial or epicardial bipolar signals at cardiac catheterization or operation were isolated, amplified and filtered through a band width of 30 to $250 \mathrm{Hertz}$ (Electronics for Medicine V1205A amplifiers) and were recorded on photographic paper moving at 100 to $150 \mathrm{~mm} / \mathrm{s}$.

\section{Results}

Electrocardiographic findings: Table I summarizes the electrocardiographic and electrophysiologic data in the seven patients. Two patients (Cases 1 and 4) exhibited preoperative right axis deviation (QRS mean electrical frontal plane axis between +90 and $+180^{\circ}$ ) which shifted slightly to the left postoperatively in one and more extensively to the left in the other. The remaining patients showed normal preoperative QRS axis excepting one (Case 7) with an indeterminant axis; among these remaining patients one (Case 3) manifested right axis deviation after operation and another (Case 2) showed a left superior mean frontal plane QRS axis $\left(-60^{\circ}\right)$ with a $Q$ wave in leads $I$ and aVL, and a small $\mathrm{K}$ wave in lead II, indicative of left anterior hem-

TABLE ।

Electrophysiologic Data

\begin{tabular}{|c|c|c|c|c|c|c|c|c|c|c|}
\hline \multirow{4}{*}{$\begin{array}{l}\text { Reported } \\
\text { Normal Values }\end{array}$} & \multicolumn{3}{|c|}{ Surface ECG } & \multirow{3}{*}{$\begin{array}{l}\text { P-R Interval } \\
\text { (ms) }\end{array}$} & & & & & & \\
\hline & \multirow{2}{*}{$\begin{array}{c}\text { QRS } \\
\text { Frontal Plane } \\
\text { Axis }\left({ }^{\circ}\right)\end{array}$} & \multirow{2}{*}{$\begin{array}{c}\text { QRS } \\
\text { Duration } \\
\text { (ms) }\end{array}$} & \multirow{2}{*}{$\begin{array}{l}\text { QRS } \\
\text { Configur- } \\
\text { ation }\end{array}$} & & \multicolumn{6}{|c|}{ His Bundle Data (ms) } \\
\hline & & & & & P-A & $\mathrm{A}-\mathrm{H}$ & $\mathrm{H}-\mathrm{V}$ & RVA & RVI & RVO \\
\hline & $20-80^{20}$ & $70 \pm 10^{20}$ & - & $140 \pm 20^{20}$ & $24 \pm 7^{21}$ & $84 \pm 17^{21}$ & $38 \pm 7^{21}$ & $26 \pm 8^{22}$ & $45 \pm 10^{22}$ & $51 \pm 11^{22}$ \\
\hline \multicolumn{11}{|l|}{$\begin{array}{l}\text { Patient values } \\
1\end{array}$} \\
\hline $\begin{array}{l}\text { Preop } \\
\text { Postop }\end{array}$ & $\begin{array}{r}105 \\
30\end{array}$ & $\begin{array}{r}60 \\
120\end{array}$ & $\begin{array}{l}\text { RVH } \\
\text { RBBB }\end{array}$ & - & - & - & - & - & - & - \\
\hline $\begin{array}{l}\text { Preop } \\
\text { Postop } \\
3\end{array}$ & $\begin{array}{r}10 \\
-60\end{array}$ & $\begin{array}{r}90 \\
120\end{array}$ & $\begin{array}{l}\text { RVH } \\
\text { RBBB }\end{array}$ & - & - & - & - & - & - & E \\
\hline $\begin{array}{l}\text { Preop } \\
\text { Postop }\end{array}$ & $\begin{array}{r}80 \\
135\end{array}$ & $\begin{array}{r}80 \\
120\end{array}$ & $\begin{array}{l}\text { RVH } \\
\text { RBBB }\end{array}$ & - & - & - & - & $\overline{45}$ & $\overline{67}$ & $\overline{105}$ \\
\hline $\begin{array}{l}4 \\
\text { Preop } \\
\text { Postop }\end{array}$ & $\begin{array}{l}60 \\
60\end{array}$ & $\begin{array}{r}60 \\
120\end{array}$ & $\begin{array}{l}\text { Normal } \\
\text { RBBB }\end{array}$ & $\overline{145}$ & $\overline{25}$ & $\overline{80}$ & $\overline{40}$ & $\overline{44}$ & $\overline{90}$ & $\overline{92}$ \\
\hline $\begin{array}{l}5 \\
\text { Preop } \\
\text { Postop }\end{array}$ & $\begin{array}{r}105 \\
90\end{array}$ & $\begin{array}{r}70 \\
100\end{array}$ & $\begin{array}{l}\text { RVH } \\
\text { RVCD }\end{array}$ & $\overline{144}$ & $\overline{30}$ & $\overline{69}$ & $\overline{45}$ & $\overline{40}$ & $\overline{59}$ & $\overline{89}$ \\
\hline${ }^{6}$ Preop & 30 & 100 & RVCD & - & - & - & - & - & - & - \\
\hline $7^{\text {Postop }}$ & 30 & 100 & RVCD & 150 & 32 & 85 & 34 & 15 & 53 & 43 \\
\hline $\begin{array}{l}\text { Preop } \\
\text { Postop }\end{array}$ & $\begin{array}{l}\text { Indet } \\
\text { Indet }\end{array}$ & $\begin{array}{l}100 \\
100\end{array}$ & $\begin{array}{l}\text { RVCD } \\
\text { RVCD }\end{array}$ & 一 & - & - & - & - & & $=$ \\
\hline
\end{tabular}

$A-H=A$ to $\mathrm{H}$ interval; $\mathrm{ECG}=$ electrocardiogram; $\mathrm{H}-\mathrm{V}=\mathrm{H}-\mathrm{V}$ interval; indet $=$ indeterminate; $\mathrm{P}-\mathrm{A}=\mathrm{P}-\mathrm{A}$ deflection interval; $\mathrm{RBBB}=$ right bundle branch block; RVA = right ventricular apex activation time; $R$ RH = right ventricular hypertrophy; $R V I=$ right ventricular inflow activation time; RVO = right ventricular outflow activation time. Superscript numbers in column headings refer to references. 
iblock. No axis shift was induced by surgery in the remainder. Four patients (Cases 1 to 4 ) showed a complete right bundle branch block pattern (deep and slurred $S$ waves in leads $\mathrm{I}$ and $\mathrm{V}_{6}$; broad rsR pattern in lead $\mathrm{V}_{1}$; and a QRS duration equal to or greater than $0.12 \mathrm{sec}-$ ond). Three patients (Cases 5 to 7 ) had only a right ventricular conduction delay in the postoperative electrocardiogram (shallow $S$ wave in leads $I$ and $V_{6}$; rsr pattern in lead $\mathrm{V}_{1}$; and a QRS duration of less than 0.12 second) and in two of these there was no change in QRS duration from the preoperative value.

Electrophysiologic findings: Figure 1 displays the activation maps of the right ventricular epicardial excitation in Patient 1 with low and Patients 2 and 3 with high type of double chamber right ventricle, respectively. The right ventricular epicardial breakthrough of the advancing wave front began $10 \mathrm{~ms}$ (Patient 1), 23 ms (Patient 2) and $24 \mathrm{~ms}$ (Patient 3) after myocardial activation (QRS onset). The breakthrough point in each was located over the pretrabecular area at a point more than 50 percent of the distance from the pulmonary valve to the right ventricular apex. The wave front then spread tangentially to the right ventricular conus and A-V groove. By contrast, examination of the epicardial surface for a "dimple" depression (marking the free wall insertion of the obstructing muscle band) and direct inspection of the muscle band in the opened right ventricle showed that the area of anatomic obstruction was clearly superior to the early electrical breakthrough point. Furthermore, in both patients studied (Cases 2 and 3 ) recordings from the endocardial surface of the obstructing muscle bundle before its surgical division failed to show specialized conduction tissue electrograms.

His bundle intervals were normal in the three patients studied at cardiac catheterization after operation. Right ventricular apical endocardial activation times in the four patients (Cases 3 to 6 ) were $45,44,40$, and 15 $\mathrm{ms}$, respectively. The latter two values are normal and the first two are only $3 \mathrm{~ms}$ outside 2 standard deviations
A.

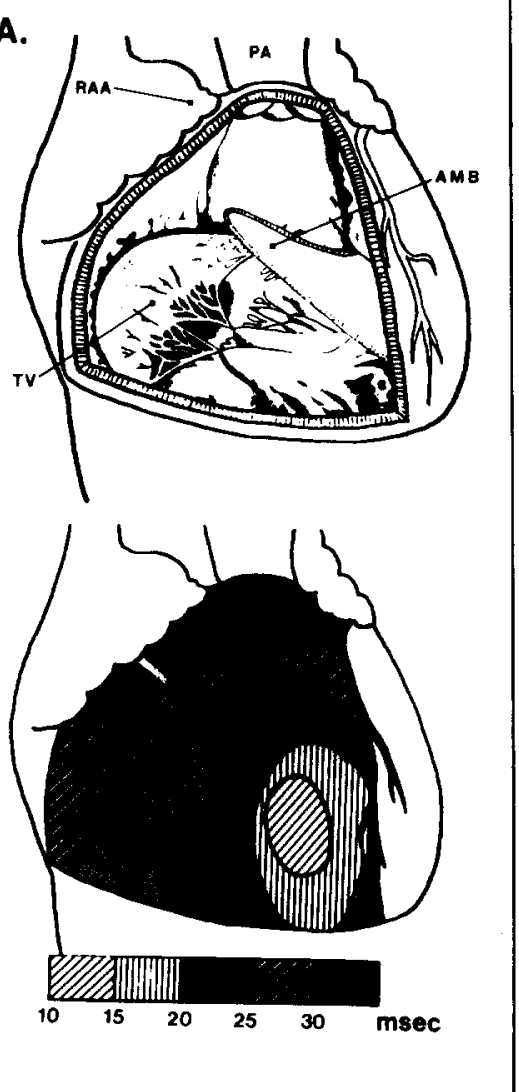

B.

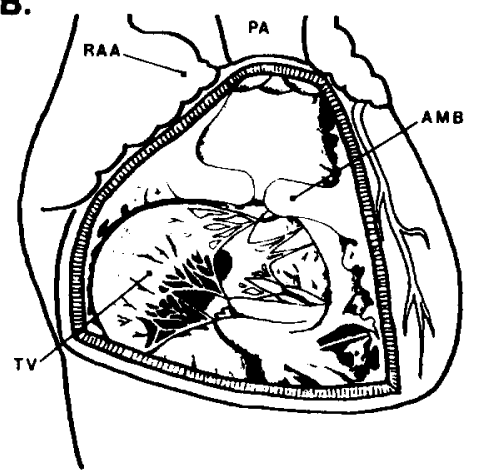

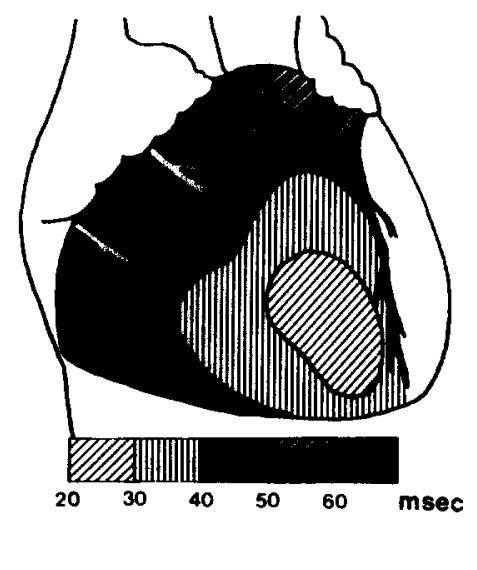

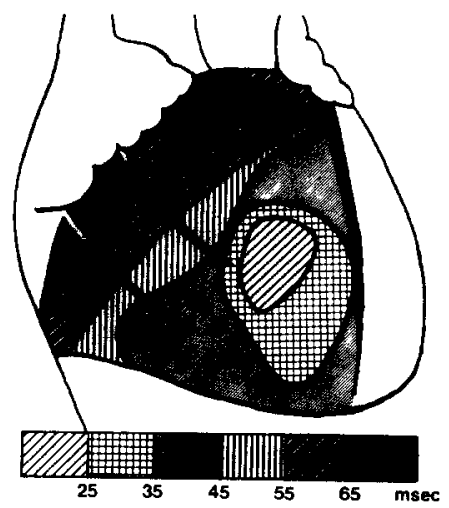

FICURE 1. A, schematic diagram (above) from the angiogram of Patient 1 demonstrating a low type of obstructing muscle band with double chamber right ventricle. The surface excitation map of the anterior free wall of the right ventricle (below) demonstrates a normally located early breakthrough point closer to the apex than to the pulmonary valve. This point, which does not coincide with the site of the obstructing muscle band, marks the location of the right bundle branch of specialized conduction tissue. B, schematic diagram from the angiograms (above) and the surface excitation maps (below) from Patients 2 and 3 with a high type of double chamber right ventricle. (The additional lesion of double outlet right ventricle found in Patient 3 is not depicted in the diagram.) The discrepancy between the anatomic and electrophysiologic findings underscores even more than in Patient 1 the dissociation between the obstructing muscle band and the right bundle branch. Note that in $B$ a portion of the conus is activated earlier in relation to the total right ventricular activation time than in $\mathbf{A}$ (see text for discussion). AMB = anomalous obstructing muscle band; $\mathbf{P A}$ = pulmonary artery; RAA = right atrial appendage; $\mathrm{TV}=$ tricuspid valve. 
from the mean of normal. Terminal right ventricular endocardial activation was within $30 \mathrm{~ms}$ of the end of the QRS complex in Patients 4 and 5 with the delay occurring at both the inflow and outflow regions in Patients 3 and 4 and in the right ventricular outflow tract alone in Patient 5. Patient 6, like Patient 5, had a normal QRS duration (100 seconds) after operation, and both right ventricular outflow activation $(43 \mathrm{~ms})$ and inflow activation $(53 \mathrm{~ms})$ were normal.

\section{Discussion}

Normal epicardial right ventricular activation: The normal sequence of right ventricular epicardial activation has been established in the human heart. ${ }^{1,5}$ In both the normal ${ }^{1-3}$ and some forms of the abnormal $^{23,24}$ heart, the anatomic course of the right bundle branch proceeds along the lower margin of the crista supraventricularis to reach the moderator band below the papillary muscle of the conus (muscle of Lancisi). It traverses the moderator band to reach the angle formed by it and the anterior papillary muscle where it divides into three terminal rami continuous with the Purkinje network of the inferior and anterior right ventricular walls and the lower septal surface. ${ }^{3}$ No branching of the right bundle proximal to the moderator band had been demonstrated (Lev M, personal communication, 1980); furthermore, activation of septal endocardium above the moderator band results from transseptal excitation from the left bundle branch. ${ }^{4}$ Both endocardial and epicardial activation sequences of the right ventricle reflect this anatomic configuration. The spread of epicardial excitation resulting from right bundle activation starts near the base of the anterior papillary muscle, followed by the distal septum and anterior free wall. Breakthrough of activation on the epicardial surface occurs over the pretrabecular area where the moderator band inserts on the right ventricular anterior free wall and thus electrophysiologically marks the underlying anterior papillary muscle and moderator band. The moving wave front then proceeds in a regular tangential way ultimately reaching the pulmonary conus. The normal inferiorly postioned epicardial breakthrough point found in our three patients preoperatively suggests that the right bundle and thus the moderator band are normally placed, and are not displaced higher, as one might expect if the right bundle were contained within the obstructing band. Failure to record specialized tissue electrograms from the obstructing muscle bundle in two patients supports this interpretation.

Epicardial activation in double chambered right ventricle: Although the late tangential pattern of excitation from the breakthrough point to the conus in our patients with the two types of double chamber right ventricle was similar, the patients with the high type had slightly earlier activation of the conal region than did the patient with the low type of double chamber right ventricle. To explain the discrepancy in conal activation times between the two types of double chamber right ventricle one may postulate that the usual trans- septal excitatory wave front emerging on the right ventricular septal endocardium superior to the moderator band origin ${ }^{4}$ enters an immediately adjacent high type of obstructing muscle band. Thus, in Patients 2 and 3 conal activation results from fusion of this slightly earlier wave front conveyed by the obstructing muscle band with the normally arriving tangential epicardial wavefront. In contrast, in the low type of double chamber right ventricle (Patient 1), conal activation results from the normal tangential spread alone.

Right ventricular endocardial activation: With use of catheter techniques, the normal right ventricular endocardial activation sequence in children has been established, proceeding from the apex superiorly and rightwardly to the outflow and inflow areas, respectively. ${ }^{22}$ This pattern is similar to that recorded through directly placed electrodes in resuscitated human hearts 4 and in adults by catheter technique. ${ }^{25}$ Because our patients (Cases 3 to 6 ) were studied after ventriculotomy, disruption of the activation sequence occurred. Nonetheless, similar to the pattern seen on the epicardial maps in the three preoperative patients (Cases 1 to 3 ), normal early activation occurred in the right ventricular apex, namely, in the low lying region of a normally placed moderator band.

Several endocardial activation patterns have been identified after the development of right bundle branch block according to the level of injury in this bundle. ${ }^{18,19}$ Specifically, central right bundle branch injury results in prolongation of activation time at all three endocardial sites. Injury to the more distal right bundle branch, sustained by cutting the moderator band, preserves the normal apex activation time, but prolongs the right ventricular inflow and outflow activation. Injury to the most distal ramifications of the right bundle, secondary to ventriculotomy, results in prolongation of activation only at the specific site of injury to the Purkinje network. According to this concept, simple division of the distal moderator band, regardless of location, should preserve the normal apex activation time in the right ventricle. However, surgery to relieve the double chamber right ventricle involves a releasing of the obstructing band from its origin at the septal surface ${ }^{9}$; this technique would effectively divide the right bundle branch proximal to the point where it begins to traverse the right ventricular cavity. Because no branching of the right bundle has been shown to exist proximal to the moderator band, ${ }^{25}$ injury to the right bundle branch at this point should equate to proximal central injury and should result in a prolongation of all right ventricular activation times. Postoperative endocardial activation data in our three patients (Table I) demonstrate normal apex activation times after relief of obstruction.

In summary, these data indicate that activation of the double chamber right ventricular is normal and that, after relief of obstruction, early activation is unchanged. These findings suggest that the obstructing muscle bundle in double chamber right ventricle is not the moderator band but rather a truly "anomalous muscle bundle of the right ventricle."'6 


\section{References}

1. Bharatl $S$, Lev $M$. The anatomy and pathology of the conduction system. In: Samet P, Nabit E, eds. Cardiac Pacing. New York: Grune \& Stratton, 1980:1-35.

2. Massing CK, James TN. Anatomy and pathology of the conduction system. In Ref. 1, 17-46.

3. McAlpine WA. An Anatomical Atlas for Clinical Diagnosis, Radiological Investigation, and Surgical Treatment. New York: Springer-Verlag, 1975;67-77.

4. Durrer E. vanDam RTH, Freud GE, Janse MJ, Meljier FL, Arsbaecher RC. Total excitation of the isolated human heart. Circulation 1970;41:899-909.

5. Wyndham CR, Meeran MK, Smith T, et al. Epicardial activation of the intact human heart without conduction defect. Circulation 1979;59:161-8.

6. Lucas RV, Varco RL, Lillehei CW, Adam P. Anomalous muscle bundle of the right ventricle. Circulation 1962;25:443-55.

7. Hartmann AF Jr, Goldring D, Carlson E. Development of right ventricular obstruction by aberrant muscle band. Circulation 1964;30:679-85.

8. Coates JR, McClenathan JE, Scott LP. The double chambered right ventricle. A diagnostic and operative pitfall. Am J Cardiol $1964 ; 14: 561-7$.

9. Warden HE, Lucas RV Jr, Varco RL. Right ventricular obstruction resulting from anomalous muscle bundles. $J$ Thorac Cardiovasc Surg 1966;51:53-63.

10. Forster JE, Humphries JO. Right ventricular anomalous muscle bundle. Circulation 1971;43:115-27.

11. Rowland TW, Rosenthal A, Castaneda AR. Double chambered right ventricle; experience with 17 cases. Am Heart J 1975;89: 455-62.

12. Fellows KE, Martin EC, Rosenthal A. Angiocardiography of obstructing muscular bands of the right ventricle. Am J Roentgenol 1977;128:249-56.

13. Hartmann AF Jr, Telfutls AA, Arvideson $H$, Goldring D. The two chambered right ventricle. Report of nine cases. Circulation 1978;26:279-87.

14. Baumstark A, Fellows KE, Rosenthal A. Combined double chambered right ventricle and discrete subaortic stenosis. Circulation 1978;57:299-303.
15. Dick M, Norwood WI, Chipman C, Castaneda AR. Intraoperative recording of specialized atrioventricular conduction tissue electrograms in 47 patients. Circulation 1979;59:150-60.

16. Dick M, Behrendt DM, Jochim KE, Castaneda AP. Electrophysiologic delineation of the intraventricular $\mathrm{His}$ bundle in two patients with endocardial cushion type of ventricular septal defect. Circulation 1981;63:225-9

17. Gallagher JJ, Kasell J, Sealy WC, Pritchett ELC, Wallace AG. Epicardial mapping of the Wolff-Parkinson-White syndrome. Circulation 1978;57:854-66.

18. Horowitz LN, Alexander JA, Edwards LH Jr. Postoperative right bundle branch block: identification of three levels of block. Circulation 1980;62:319-28.

19. Krongrad E, Heller SE, Bowman FO Jr, Malon JR, Hofiman BF, Further observation on the etiology of right bundle branch block pattern following right ventriculotomy. Circulation 1974;50: 1105-13.

20. Llebman J, Plonsey R. Electrocardiography. In: Moss AJ, Adams FH. Emmanouilides GC, eds. Heart Disease in Infants, Children and Adolescents. Baltimore: Williams \& Wilkins, 1977:31-7.

21. Roberts NK, Glllette PC. Clinical electrophysiologic data in the investigation of an arrhythmia: a review of techniques and normal values. In: Roberts NK, Gelband H, eds. Cardiac Arrhythmias in the Neonate, Infant and Child, New York: Appleton-Century-Crofts, 1977:133-57.

22. Dick M, Hougen TJ, Keane JF. Right ventricular activation measured by catheter technique: values in children and influence of high and low filters (abstr). Pediatr Res 1978;12:380.

23. Bharati $\mathbf{S}$, Lev $\mathbf{M}$. The conduction system in double outlet right ventricle with subpulmonic ventricular septal defect and related hearts (the Taussig-Bing group). Circulation 1976;54:459-67.

24. Bharali S, Lev M. The conduction system in simple, regular (d-) complete transposition with ventricular septal defect. J Thorac Cardiovasc Surg 1976;72:194-201.

25. Kastor JA, Goldreyer BN, Moore EN, Shelburne JC, Manchester $\mathrm{JM}$. Intraventricular conduction in man studied with an endocardial electrode catheter mapping technique. Patients with normal QRS and right bundle branch block. Circulation 1975;51:786-96. 